ILA الجمعية المصرية للقر اعة والمعرفة عضو الجمعية الدولية للمعرفة

\title{
TEACHERS' PERCEPTION OF THE EFFECT OF TECHNOLOGY ON STUDENTS' ENGAGEMENT IN THE MIDDLE SCHOOL SCIENCE CLASSROOM
}

\author{
MASTER THESIS SUMMARY
}

Tahani Alghamdi, School of Education, Felician College, Rutherford, New Jersey, July 2014 


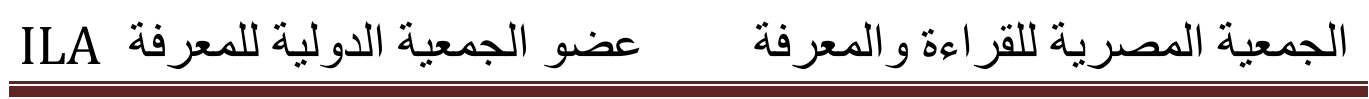


The purpose of this Master's thesis “Teachers' Perception of the Effect of Technology on Students' Engagement in the Middle

School Science Classroom" was to determine teachers' perceptions about the effectiveness of technology in middle school science classroom on student engagement. The Master's thesis is composed of five chapters, each of them dealing with different aspect of the research that was conducted.

Chapter 1 is introductory and describes the relationship between technology, students, and the science classroom. Chapter 2 examines literature reviewed in conjunction with the Master's thesis. Chapter 3 provides an outline of relevant methodology used in the study. Chapter 4 concentrates on the results of the study. Conclusions are drawn in Chapter 5, with the main aim of the graduation thesis having been reached.

\section{CHAPTER 1: INTRODUCTION}

The problem identified in the Master's thesis was focused on the increasing use of technology in the classroom, especially in the 


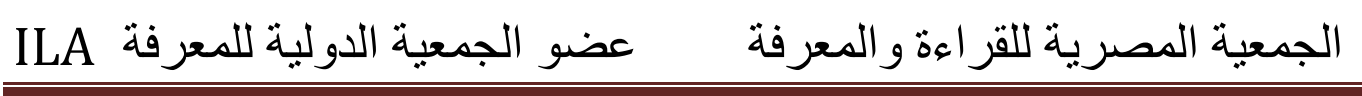

science classroom. However, some believe that it is distracting to students and teachers, which can impact student engagement. Teachers have observed that students who are bored with school become disengaged with academic and social aspects of school. This is a problem for schools and students. Science classes can be an area of low success and engagement. When a student is not motivated nor engaged, they are unable to learn the material needed to pass the classes.

Educators today are trying to find new ways to engage students in curriculum. As technology has permeated all sectors of our lives, educators have experienced pressure to reform schools with the use of technology. Moreover, students also request technology in the classroom as they find it to be more useful and effective in teaching, that it increases their motivation to learn, and increases confidence in the subject (Li, 2007). Science classes can be difficult for students, as explained in the problem statement. This study, therefore, 
examined technology in science classrooms to see how teachers perceived it affected student engagement.

The study assessed teachers' use of technology in the classroom and how it affects student engagement, which can impact how other science teachers use technology. If science teachers notice technology in the classroom helps student engagement, more classrooms may implement it. Furthermore, the study can impact how often technology is used and what is more useful.

Three research questions formed the basis of this Master's thesis. They are:

1. What are teachers' perceptions of the relationship between integration of technology into the science classroom and student engagement?

2. How do middle school science teachers integrate technology in the science classroom? 


\section{الجمعية المصرية للقر اعة والمعرفة عضو الجمعية الدولية للمعرفة}

3. Why do science teachers have these perceptions about the integration of technology into the science classroom and student engagement?

The study used a descriptive approach as teachers reported perceptions about the use of technology, examined how teachers already used technology in their classrooms, and sought to understand whether the use of technology has an impact on students' engagement level. A population of science teachers was described, common links were observed, and recommendations were made based on these observations and descriptions.

The primary assumption was that the survey respondents were representative of science teachers in New Jersey and that the findings could be applied outside the scope of the study. However, the study was limited insofar as it was conducted via an online survey, which might create an inherent bias if teachers already using technology were more likely to respond and also limited the available pool of respondents. An online survey was chosen rather 


\section{الجمعية المصرية للقر اعة والمعرفة عضو الجمعية الدولية للمعرفة المي}

than in-person interviews of teachers in New Jersey schools due to budget constraints, time constraints, and because the New Jersey

Science Teachers Association provides access to a large population of science teachers. The survey results were obtained by a request for participation on the New Jersey Science Teacher Associate website. All results remained anonymous. Participation in the survey was voluntary. The survey was conducted online using SurveyMonkey.

\section{CHAPTER 2: LITERATURE REVIEW}

\section{The teachers' perception of the relationship between integration of technology into the science classroom and student engagement}

It appears that the teachers' perception of technology in the science classroom and student engagement depends on the teachers' and the student's attitude. Capobianco \& Lehman (2006) studied the use of productivity software and probeware integrated into an elementary science methods course using interviews and reflective journals. Out of the 20 teacher participants, $60 \%$ supported the use of technology because it helps students design investigations, collect data, and 


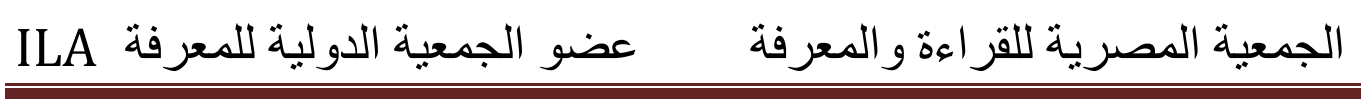

communicate the results. The journals showed an interest in integrating instructional technology in their classrooms. This research shows that teachers must create an awareness of technology in order to use it and have opportunities to reflect on its role in their classrooms. Nicholas and $\mathrm{Ng}$ (2009) produced similar findings in a study that focused on a framework for analyzing technology supporting teaching activities. Accordingly, teachers modify technology use to suit the school, classroom settings, and pedagogical approaches. Bacanak (2013) examined teacher perceptions of the effectiveness and functionality of the teaching learning process of primary Science and Technology curriculum using a qualitative research design involving 52 science and technology teachers from primary schools in Turkey. The results showed that $75 \%$ of the teachers supported science and technology curriculum because they were able to meet the outcomes effectively. La-Roche and Flanigan (2013) also examined student use of technology in science classes by surveying over 200 undergraduate 


\section{الجمعية المصرية للقر اعة والمعرفة عضو الجمعية الدولية للمعرفة المي}

students. All but one student had laptops and over half reported they use them in class. However, only $8.5 \%$ of the students had iPads, but over half of them did not use them in class. Their teachers viewed technology as helpful because the students could find answers easily, which increased performance. However, this research did not address engagement between the teacher and the students. Integrating technology into the science classroom and student engagement can guide teachers on which mode of teaching to apply. Ferreira, Baptista, and Arroio (2013) carried out a qualitative study to analyze strategies for teaching science based on the mode of teaching, specific context, and student engagement. The results of semi-structured interviews found all the teachers employed multimedia tools to teach the concepts of technology in science classrooms, and students actively engaged in science activities. This research showed that teachers appreciated the use of technology but need a high level of competence to integrate the tools in science classes. A previous study by Hsieh and Cifuentes (2006) examined 


\section{الجمعية المصرية للقر اعة والمعرفة عضو الجمعية الدولية للمعرفة}

the use of visualization as a learning strategy for middle school science students using both qualitative and qualitative methods. Using the data from a science test administered in class, the results showed no significant variation among students based on the extent to which they had been exposed to the topics. Overall, visualization techniques in both pencil-and-paper and computer methods helped students perform better, although students engaged in more off-topic activities when they used computers. Students demonstrated they could better understand what they read through the visualization strategy. Therefore, the results showed that teachers use technology so students can understand meaningful concepts. Digital literacy has also been used as a method of integrating technology in the science classroom. Research conducted by $\mathrm{Ng}$ (2011) focused on the digital perspective of technology by examining the presence of Web 2.0 technologies, which allows students to build social spaces. The study showed that learning could take place within and outside the 


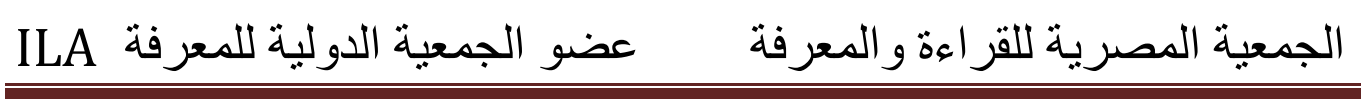

classroom with mobile devices, and the role of the teacher was to empower the student with multiple places of learning.

As these various studies showed, the integration of technology in the classroom depended on student engagement in the learning process. Perceptions about the integration of technology into the science classroom depended on teachers' competence and the level of teaching. Teachers need to learn to use technology effectively and integrate it into the learning process to provide significant engagement for their students. This research went further than simply indicating what technology is useful by demonstrating that teachers who learn to use technology themselves provide significant student engagement, which in turn permitted students to involve themselves in the process of learning.

\section{Technology integration into the middle school science classroom}

Technology can promote positive study strategies. In one study conducted by Hsieh \& Cifuentes (2006), students were trained to use visualization to determine how the use of a computer was different 


\section{الجمعية المصرية للقر اعة والمعرفة عضو الجمعية الدولية للمعرفة المي}

from the use of paper and how both of them differed from no visualization at all. In this mixed-methods study, the visualization groups performed better than the control group with no visualization in terms of test scores and study skills, and they had better focus and more purposeful activity. However, the group with the computers reported it took too long to visualize using computers. This indicated that technology must be easy to use and provide added benefit. In another study, it was found that technology can be used to help students with learning techniques (Moote, Williams, \& Sproule, 2013). They found that students who engaged in self-regulated learning via technology had significantly higher test scores than students who did not.

In the middle school science classroom, it might not be practical to provide every student with a laptop or a tablet computer to ensure they all have access to technology. However, a personal computer is not the limit of technology potential. Handheld computing devices which measure temperature from probes and other such information 


\section{الجمعية المصرية للقر اعة والمعرفة عضو الجمعية الدولية للمعرفة}

are also highly useful for the science classroom. In one study of preservice science teachers, the class used handheld computing devices as lab equipment to measure and analyze data. After they became comfortable with the equipment, they quickly began creating their own problems to research using their equipment (Gado, Ferguson, \& Van 'T Hooft, 2006). However, it was noted that the adult preservice teachers may have displayed a different set of interests and motivations than the average middle-school student may have. In another study, researchers found that after teachers were taught how to use technology in their classrooms, they were happy to use it and saw positive results from their students in terms of interest and comprehension (Capobianco \& Lehman, 2006).

Tablet computers seemed to be especially useful to enhance lab experiences because of their versatility. In a study conducted in a university general chemistry lab, students were issued iPads to create a completely paperless lab (Hesser \& Schwartz, 2013). They used their iPads to take photos of the lab process and document the lab as 


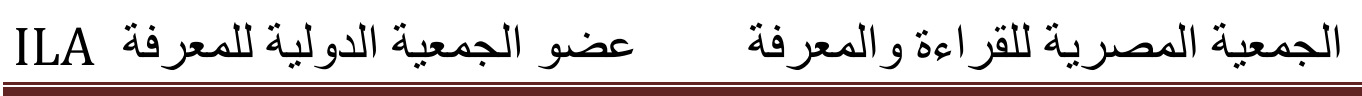

they performed it. They also used the Blackboard learning system to keep track of their assignments online and to interact with the instructors and other students outside class. Students reported that iPads were far more useable in the laboratory than laptops would have been. This study in tablet computers pointed toward technology as an all-in-one tool for communication and classroom management. Technology to support lectures can also be highly effective, especially when used to promote student participation. One promising piece of technology for encouraging students to participate is called an audience response system, or ARS, more commonly known as clickers, which are wireless devices that allow students to interact, answer questions, and ask their own questions. In a pilot study of nursing students, it was found that ARS was an effective way for an entire class to be able to participate in a lesson (Filer, 2010). While nursing students are different than middle school science students, the potential for effective learning using ARS in a middle school class is perhaps greater because it allows 


\section{الجمعية المصرية للقر اعة والمعرفة عضو الجمعية الدولية للمعرفة المي}

students to submit questions and answers instantly and anonymously.

Computer technology is also a powerful tool for students to be able to do research. One study of middle school students examined their use of technology for doing research and presenting to their classmates. Students reported feeling a high degree of interest in the topics they learned doing their online research and collaborative projects, and teachers reported that students learned and engaged ideas to an impressive and satisfactory depth (ChanLin, 2008). This is another example that showed technology can be highly effective in the classroom but that teachers must have expertise and the time to teach the students how to use technology.

Integrating technology into classrooms can be difficult, which made studies of schools that have accomplished technology integration especially notable. In one study of three high schools that had integrated one computer per student, the students were using technology to support classroom interaction, do internet research, 


\section{الجمعية المصرية للقر اعة والمعرفة عضو الجمعية الدولية للمعرفة}

and communicate with each other and with the teachers (Drayton,

Falk, Stroud, Hobbs, \& Hammerman, 2010). However, teachers and

students were hampered by technical problems, and keeping students on task during class time was an issue of classroom management.

How technology is used in the classroom is also important to student achievement. In one study of middle school science students, a problem-based learning program was enriched using new media and technology. The results showed that students demonstrated significantly higher levels of engagement and success, both in terms of their reported enjoyment and in a comparison of test scores (Liu, Horton, Olmanson, \& Toprac, 2011). Outside of the classroom, computer technology can be used to foster online learning. It enables students to interact with instructors, classmates, and information that is available online. In one mixed-methods study of students who used an online learning program, it was found that online learning helped stimulate depth of thought on the part of the students (Nicholas \& Ng, 2009). 


\section{الجمعية المصرية للقر اعة والمعرفة عضو الجمعية الدولية للمعرفة ILA}

\section{Science teachers' perceptions about the integration of technology into the science classroom and student engagement}

Teachers' beliefs about technology and previous experience with technology affect the way they use it in the classroom. A case study of two middle school math and science teachers was conducted after students had been issued laptops (Garthwait \& Weller, 2005). Both of the teachers had a positive view of technology in the classroom.

One of the teachers noted that her students were more engaged and motivated in their work due to having laptops, which seemed to be due to a combination of her instruction and their use of the computers. The other teacher noted that laptops helped him take advantage of teachable moments and embrace his spontaneous teaching style. It was notable that both teachers expected technology to work well in their classrooms, so it is likely that the technology conformed to their positive expectations. The level of knowledge that teachers have about technology is important to teachers' opinions of technology and related fields in general. For example, one study was designed to discover middle school science and 


\section{الجمعية المصرية للقر اعة والمعرفة عضو الجمعية الدولية للمعرفة المي}

technology teachers' opinions about technology and how it relates to entrepreneurship skills in students (Bacanak, 2013). Semi-structured interviews revealed the teachers believed that teachers' own entrepreneurial spirit and lessons in entrepreneurship had a large but vague effect on students' entrepreneurial abilities. It was apparent that teachers did not understand entrepreneurship; therefore, they had practically no idea whether their science and technology classes contributed to student entrepreneurship. In other words, tools are not enough if the teacher does not have the foundational knowledge to make full use of them.

When teachers think of integrating technology into the classroom, they often think of multimedia presentations and technological support for their lessons and lectures. In a study of teachers in training, it was found that many teachers primarily focus on lecture support in their technology use. The teachers were far less likely to link their use of technology with the actual lesson they were teaching and even less so to let their students use the technology themselves 


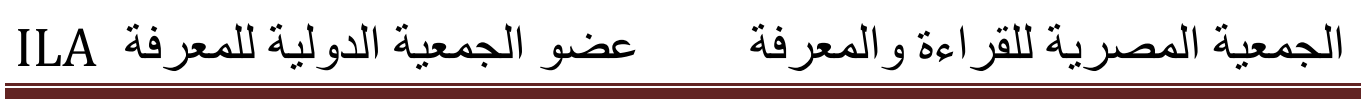

(Ferreira, Baptista, \& Arroio, 2013). This finding underscored the principle that even teachers who believe themselves to be adept at using technology are not necessarily using it to the best advantage. The amount of time it takes to learn and implement technology use in the classroom may be a deciding factor in its success. In a qualitative study of science and technology teachers, it was found that even when teachers are responsible for teaching technology, they are less likely to implement it in their own classrooms if they feel pressured for time (Gecer \& Ozel, 2012). The teachers reported that the amount of time it would take them to use it in their classrooms was simply too great for them to be able to do it and also fulfill all other requirements.

One reason for technology being viewed as negative is because it is easy for students to use technology as a form of retreatism or rebellion. In a study by LaRoche and Flanigan (2013), students were polled regarding their use of technology in class. The authors reported that students with laptops and tablet computers were likely 


\section{الجمعية المصرية للقر اعة والمعرفة عضو الجمعية الدولية للمعرفة المي}

to use their technology for taking notes, and for looking up information to contribute to class discussions. However, students also reported using their technology for activities such as social media and playing games. Furthermore, students also reported that their primary use of smart phones was texting and social media. Therefore, it is reasonable for teachers to be suspicious of allowing technology into their classrooms when students themselves report using it for reasons that are counterproductive to the classroom goals of teaching and learning. However, it is essential to listen to what students say they want in a classroom to increase their motivation and engagement. In one study of middle-grade students, it was noted that students often use technology in the same fast-paced and multitasking way that modern professionals do, but in the school environment, students are often required to separate themselves from their technology use (Spires, Lee, \& Turner, 2008). Thus, students feel that teachers do not understand the importance of technology to 


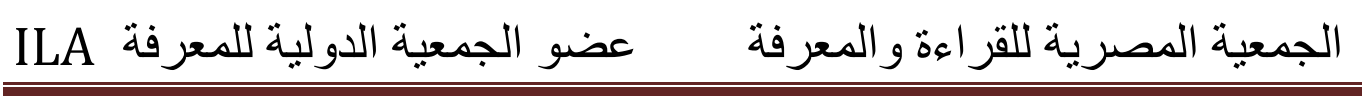

students' lives because they do not see the importance of technology to the digital native generation of students.

\section{CHAPTER 3: METHODOLOGY}

The research problem identified was the lack of agreement on the effectiveness of technology in enhancing student engagement in middle school science classrooms, which emerged after reviewing previous literature on science teachers' perceptions about the effectiveness of technology in middle school science classroom on student engagement. As a result, there was a need to further explore this problem. The study employed a quantitative approach because it requested the responding science teachers to report their attitudes and perceptions about the use of technology, examined the way those teachers already used technology in their classrooms, and sought to understand whether the use of technology had an impact on students' engagement level. The dependent variable in this study was the student's engagement level in science classes, while the 


\section{الجمعية المصرية للقر اعة والمعرفة عضو الجمعية الدولية للمعرفة المي}

independent variables were the various approaches to the application of technology in the classroom.

Survey data was collected from the New Jersey Science Teachers Association website through Survey Monkey, a website that facilitates online surveys website. The New Jersey Science Teachers Association provided permission to post a brief notice of the survey on their web page, which served as an invitation to interested science teachers to participate in the survey. A limit on the number of responses was set at 100 in consideration of the limitations of time and resources that might be needed to analyze the survey data. Furthermore, Survey Monkey set a limit on the period of availability at two weeks.

The New Jersey Science Teachers Association is an established organization that promotes professional development and collaboration. A convenience sample of science teachers was obtained by seeking permission to post the survey link on the association's website, which provided easy access to the science 


\section{الجمعية المصرية للقر اعة والمعرفة عضو الجمعية الدولية للمعرفة المي}

teachers in New Jersey, who were the target population. The teachers were required to voluntarily answer the survey questions, including aspects of their attitudes and student attitudes toward technology in their science classes.

Materials included a consent letter to the president of the New Jersey Science Teachers Association and an invitation letter on the New Jersey Science Teachers Association website, calling on teachers to participate in the survey. A consent letter was drafted as the first point of interaction between the survey and the participants. The survey questions were uploaded on the Survey Monkey website.

A Likert-type survey was created for the study to collect survey data. Various responses from the teachers were measured on the following Likert-type scale: 1) never, 2) seldom, 3) sometimes, 4) usually, and 5) always.

The online survey was active and open for participation over a period of two weeks. The survey data obtained was then analyzed by 


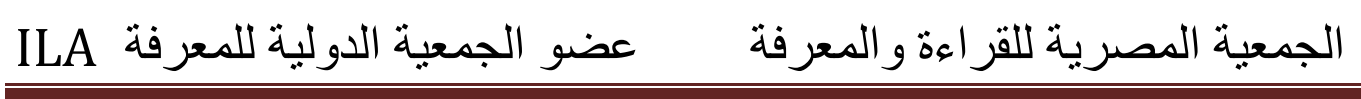

Survey Monkey and the results were sent to the researcher for review.

After analysis, SurveyMonkey presented the results and findings in the form of charts and graphs, and offered accompanying explanations and other relevant information. The charts and graphs provided a visual presentation of the teachers' perceptions on the effectiveness of technology to enhance student engagement by presenting the answer to the survey questions.

\section{CHAPTER 4: RESULTS}

The Science Teachers' Perceptions of the Relationship between Integration of Technology into the Science Classroom and Enhancing Student Engagement

One survey question asked what specific student behaviors teachers observed that related to the level of student engagement when using technology. Teachers were asked if paying attention was a behavior they observed when using technology. There were $4.76 \%$ who responded that students seldom pay attention, $47.62 \%$ who perceived that students pay attention sometimes, $28.57 \%$ who perceived they 


\section{الجمعية المصرية للقر اعة والمعرفة عضو الجمعية الدولية للمعرفة}

usually pay attention, and $19.05 \%$ of who perceived that students always pay attention when using technology. Teachers were also asked how they perceived students focused on an assignment when using technology. There were $9.52 \%$ who responded seldom, $28.57 \%$ who responded sometimes,33.33\% who responded usually, and $28.57 \%$ who responded always. Teachers were also asked if they perceived students engaged in taking notes when using technology. There were $14.29 \%$ of them who felt it never occurred never, $23.81 \%$ who responded it occurred seldom, $14.29 \%$ who responded with sometimes, $33.33 \%$ with usually, and $14.28 \%$ who responded with always. Prompting students to ask questions was another behavior that teachers were asked if they perceived. In this case, $25 \%$ replied seldom, $40 \%$ replied sometimes, $20 \%$ replied usually, and $15 \%$ indicated it always occurred. Teachers were then asked if they perceived that students were engaged because they were responding to questions. There were $14.29 \%$ who replied seldom, sometimes was indicated $38.10 \%$ who responded 
sometimes, $33.33 \%$ who responded usually, and $14.29 \%$ who responded always. Finally, teachers were asked how they perceived students interacted with peers. There were $9.52 \%$ responded who that it seldom occurred, $19.05 \%$ who responded sometimes, $42.86 \%$ who believed it usually occurred, and $28.57 \%$ who thought it always occurred. Another behavior identified by teachers included using technology as a distraction by sharing pictures, texts, and music. Overall, the results indicated that interacting with peers was perceived as the most common behavior observed, and taking notes was perceived as the least most common.

\section{How Middle School Science Teachers Integrate Technology in Their Science Classrooms to Enhance Student Engagement Levels}

One survey question asked teachers to identify the usage frequencies for iPads, iPhones, computers, smart boards, and calculators. iPads were never used by $33.33 \%$ of the teachers, seldom used by $23.81 \%$, sometimes used by $33.33 \%$ of the teachers, and usually used by $9.52 \%$. iPhones were never used by $71.43 \%$ of the teachers, seldom 


\section{الجمعية المصرية للقر اعة والمعرفة عضو الجمعية الدولية للمعرفة المي}

used by $23.81 \%$, and sometimes used by $4.76 \%$. Computers were seldom used by $4.76 \%$ of the teachers, sometimes by $28.57 \%$, usually by $57.14 \%$ and always by $9.52 \%$ of the teachers. Smart boards were used sometimes by $14.29 \%$ of the teachers, often by $33.33 \%$, and always by $52.38 \%$. Calculators were never used by $19.05 \%$ of the teachers, seldom by $28.57 \%$, sometimes by $19.05 \%$, often by $28.05 \%$, and always by $4.76 \%$. Overall, smart boards held the highest ranking of use and calculators the lowest.

Teachers were also asked how they integrated technology in their science classrooms. The activities included in the survey were interactive activities, research, and assessment. There were $9.52 \%$ of the teachers who reported they seldom integrated interactive activities, $38.10 \%$ who sometimes did, $38.10 \%$ who usually integrated interactivities, and $14.29 \%$ who said they always integrated interactive activities. Research was never integrated by $4.76 \%$ of the teachers, seldom also by $4.76 \%$, sometimes by $9.52 \%$, usually by $61.90 \%$, and always by $19.05 \%$ of them. As far as 


\section{الجمعية المصرية للقراءة والمعرفة عضو الجمعية الدولية للمعرفة ILA}

assessment, 4.76\% never used technology, 19.05\% seldom used it, $47.62 \%$ of the teachers who sometimes used it, $19.05 \%$ replied usually, and $9.52 \%$ replied always. Overall, research had the highest use and assessment the lowest.

\section{Why Science Teachers have These Perceptions about the Integration of Technology into the Science Classroom and Student Engagement}

Teachers were asked to respond regarding the ways in which technology affects student engagement. The choices included accommodation to different learning styles, increase in participation, mirroring real-life experiences in the classroom, multimedia capabilities, and enhanced note-taking. There were $19.05 \%$ of the teachers who replied technology sometimes affected engagement, usually by $33.33 \%$, and always by $47.62 \%$. There were $14.29 \%$ of the teachers who responded that increase in participation seldom enhanced engagement, usually by $47.62 \%$ of the teachers, and always by $38.10 \%$. Regarding mirroring of real-life experiences, seldom was selected by $9.52 \%$ of the teachers, sometimes by 
$19.05 \%$, usually by $57.14 \%$, and always by $14.29 \%$. Concerning the effect of multimedia capabilities, $19.05 \%$ felt it seldom affected engagement, $33.33 \%$ who replied sometimes, $28.57 \%$ who said usually, and $19.05 \%$ who said it always had an effect. There were $14.29 \%$ of the teachers who felt enhanced note-taking never enhanced engagement, $28.57 \%$ who felt it seldom enhanced engagement, sometimes by $23.81 \%, 14.29 \%$ who replied usually, and $19.05 \%$ who thought it always enhanced engagement.

Accommodation to different learning styles was the most highly rated use, and the lowest rating was given to enhanced note taking.

\section{CHAPTER 5: DISCUSSION OF RESULTS, CONCLUSIONS, AND RECOMMENDATIONS}

One conclusion from the study was that teachers perceived that student behaviors of interacting with peers and focusing on the assignment demonstrated engagement while using technology. These responses could indicate a need for a more in-depth study of the student behaviors as it may be that interaction with peers is a characteristic of middle school students, not necessarily due to the 


\section{الجمعية المصرية للقر اعة والمعرفة عضو الجمعية الدولية للمعرفة المي}

use of technology in the classroom. Further studies might also provide information as to how a teacher perceived that a student is focused on a lesson, and how it relates to the use of technology. Another conclusion is that the two devices used the most in the middle school science classrooms were computers and smart boards, and that research was the primary way that teachers integrated technology into the science classroom. Therefore, it may be that the visual style of learning is what keeps students focused and provides the capability to interact with other students. However, the use for research does not seem to be related to behaviors teachers perceived regarding focusing on the lesson and interacting with peers, and may

also indicate a need for further study.

The two reasons most teachers see a positive relationship between integration of technology and student engagement were increasing participation and accommodating different learning styles.

Therefore, further study is needed to see how these reasons relate to the most common uses of computers and smart boards. Overall the 
study revealed that the most widely used types of technology used in the classroom are computers and smart boards. Based on the responses provided by the teachers, the student used the devices primarily for research, but at the same time the use of technology was seen to increase participation and peer interaction.

Assessing teachers' use of technology in the classroom and how it effects student engagement can impact how other science teachers use technology. The results show that science teachers perceived that technology use in the classroom contributes to an increase in student engagement. The results also demonstrated how often technology is used in middle school science classrooms, and what is useful to students and teachers.

\section{REFERENCES}


Bacanak, A. (2013). Teachers' views about science and technology lesson effects on the development of students' entrepreneurship skills. Educational Sciences: Theory and Practice, 622-629.

Capobianco, B., \& Lehman, J. (2006). Integrating technology to foster inquiry in an elementary science methods course: An action research study of one teacher educator's initiatives in a PT3 project. Journal of Computers in Mathematics and Science Teaching, 123-146.

ChanLin, L.-J. (2008). Technology integration applied to project-based learning in science. Innovations in Education and Teaching International, 55-65.

Drayton, B., Falk, J. K., Stroud, R., Hobbs, K., \& Hammerman, J. (2010). After installation: Ubiquitous computing and high school science in three experienced, high-technology schools. The Journal of Technology, Learning, and Assessment, $5-56$.

Ferreira, C., Baptista, M., \& Arroio, A. (2013). Teachers' pedagogical strategies for integrating multimedia tools in science teaching. Journal of Baltic Science Education, 509-524.

Filer, D. (2010). Everyone's answering: Using technology to increase classroom participation. Nursing Education Perspectives, 247-250.

Gado, I., Ferguson, R., \& Van 'T Hooft, M. (2006). Using handheld-computers and probeware in a science methods course: Preservice teachers' attitudes and self-efficacy. Journal of Technology and Teacher Education, 501-529.

Garthwait, A., \& Weller, H. G. (2005). A year in the life: Two seventh grade teachers implement one-to-one computing. Journal of Research on Technology in Education, 361-377.

Gecer, A., \& Ozel, R. (2012). Elementary science and technology teachers' views on problems encountered in the instructional process. Educational Sciences: Theory and Practice, 2256-2261.

Hesser, T. L., \& Schwartz, P. M. (2013). iPads in the science laboratory: Experience in designing and implementing a paperless chemistry laboratory course. Journal of STEM Education, 5-9. 
Hsieh, Y.-C. J., \& Cifuentes, L. (2006). Student-generated visualization as a study strategy for science concept learning. Educational Technology \& Society, 137-148.

LaRoche, C. R., \& Flanigan, M. A. (2013). Student use of technology in class: Engaged or unplugged? Journal of College Teaching \& Learning, 47-54.

Liu, M., Horton, L., Olmanson, J., \& Toprac, P. (2011). A study of learning and motivation in a new media enriched environment for middle school science. Educational Technology Research and Development, 249-265.

Moote, J. K., Williams, J. M., \& Sproule, J. (2013). When students take control: Investigating the impact of the CREST inquiry-based learning program on selfregulated processes and related motivations in young science students. Journal of Cognitive Education and Psychology, 178-196.

Nicholas, H., \& Ng, W. (2009). Engaging secondary school students in extended and open learning supported by online technologies. Journal of Research and Technology in Education, 305-328.

Spires, H. A., Lee, J. K., \& Turner, K. A. (2008). Having our say: Middle grade student perspectives on school, technologies, and academic engagement. Journal of Research on Technology in Education, 497-515. 


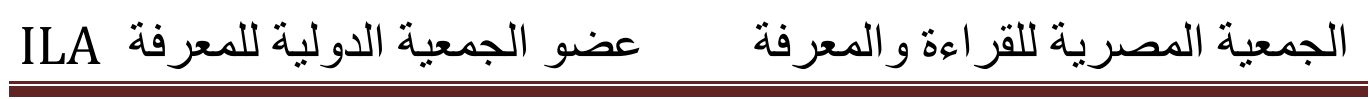

